\title{
Comparison of different DNA-extraction techniques to investigate the bacterial community of marine copepods
}

\author{
Petra Brandt • Gunnar Gerdts • Maarten Boersma • \\ Karen H. Wiltshire • Antje Wichels
}

Received: 4 May 2009/Revised: 7 December 2009/Accepted: 6 January 2010/Published online: 3 February 2010

(C) Springer-Verlag and AWI 2010

\begin{abstract}
Marine zooplanktic organisms, such as copepods, are usually associated with large numbers of bacteria. Some of these bacteria live attached to copepods' exoskeleton, while others prevail in their intestine and faecal pellets. Until now, general conclusions concerning the identity of these bacteria are problematic since the majority of previous studies focused on cultivable bacteria only. Hence, to date little is known on whether copepod genera or species harbour distinct bacterial populations and about the nature of this association. To shed more light on these copepod/bacteria consortia, the focus of this study was the development and evaluation of a suitable approach to extract bacterial DNA from different North Sea copepod genera. Furthermore, the bacterial DNA was analysed by PCR-DGGE and subsequent sequencing of excised bands. The result of this work was an appropriate extraction method for batches of ten to one copepod specimens and offered first insights as to which bacteria are attached to the copepods Acartia sp. and Temora sp. from Helgoland Roads (German Bight) and a laboratory-grown Acartia tonsa culture. It revealed the prevalence of Alphaproteobacteria.
\end{abstract}

Keywords Helgoland roads · Bacteria - Copepod . DNA extraction · DGGE

Communicated by H.-D. Franke.

P. Brandt $(\bowtie) \cdot$ G. Gerdts $~$ M. Boersma .

K. H. Wiltshire - A. Wichels

Alfred Wegener Institute for Polar and Marine Research,

Biologische Anstalt Helgoland,

PO Box 180, 27483 Helgoland, Germany

e-mail: Petra.Brandt@awi.de

\section{Introduction}

Copepods are important components of the marine food web. Their significance as a link between primary producers and higher trophic levels has long been recognised (Cushing 1989; Møller and Nielsen 2001; Møller 2005; Olsen et al. 2005). Copepods also contribute to the microbial loop (Azam et al. 1983; Møller and Nielsen 2001) by releasing dissolved organic carbon (DOC) through sloppy feeding, excretion or more indirectly by leakage of DOC from their faecal pellets (Hasegawa et al. 2001; Møller and Nielsen 2001; Møller et al. 2003; Steinberg et al. 2004) or via the decomposition of copepod carcasses by bacteria (Tang et al. 2006a, b).

Bacteria typically have a strong affinity to both biotic and abiotic surfaces (Zobell 1943; Costerton et al. 1978; Cooksey and Wigglesworth-Cooksey 1995; Carman and Dobbs 1997) and in most cases benefit from this attachment. Hence, also animal surfaces such as the chitinous exoskeleton of crustaceans can undergo extensive colonisation by bacteria (Sieburth et al. 1976; Carman and Dobbs 1997) depending on the life stage or fitness of the animal (Carman and Dobbs 1997). Using scanning electron microscopy, Nagasawa et al. (1985) found that between 0 and $100 \%$ of the members of a copepod population were colonised by bacteria, and that the epibiotic load of adult Acartia sp. can be anywhere between 10 and $10^{5}$ per specimen (Nagasawa et al. 1985; Nagasawa 1989).

From previous studies, it is known that different bacterial species show different distribution or colonisation patterns on copepods (Carman and Dobbs 1997). Especially the oral region, body appendages (Huq et al. 1983), intersegmental regions and the region around the anus (Carman and Dobbs 1997) are colonised by bacteria, 
reflecting the bacterial exploitation of DOC released by sloppy feeding or defecation (Hansen and Bech 1996).

The study of microbial epibionts on crustaceans in aquatic environments was in its infancy in 1997 (Carman and Dobbs 1997), and this situation did not change until Tang et al. (2006a, b) first investigated bacterial communities on decomposing copepod carcasses using molecular techniques such as PCR-DGGE. These studies showed that the bacterial community of freshly dispatched copepods was different from that of copepods which were incubated for some days. Møller et al. (2007) first investigated the bacterial community associated with Calanus sp. using PCR-DGGE and compared it with the community of the surrounding water. They observed that the copepod samples consisted of less than five discernable DGGE bands, whereas much higher numbers of bands could be found in the surrounding water samples. However, part of the freeliving bacteria could also be found attached to the copepods. The authors also reported that the first extraction technique they applied, an enzyme/SDS extraction protocol without use of phenol-chloroform, led to the release of PCR-inhibiting substances which required an altered DNA extraction protocol.

Therefore, not only a substantial effort in culture-independent investigations of the bacteria associated with copepods is needed, but also a proper assessment of those DNA-extraction techniques that are suited for these consortia. Only then do we stand a chance to substantially further our knowledge on the community structure and the identity of the bacteria associated with marine copepods.

Hence, the present study focuses on the evaluation of different DNA-extraction techniques of copepod-bacteria consortia. To this end, we used commercial lysis reagents and extraction kits as well as a common method such as phenol-chloroform DNA extraction. Furthermore, the bacterial community-DGGE-pattern of laboratory-grown Acartia tonsa and field-caught Acartia sp. and Temora sp. is described, and selected DGGE bands are further analysed by DNA sequencing.

\section{Materials and methods}

Sample collection and preparation

Zooplankton samples from Helgoland Roads in the North Sea $\left(54^{\circ} 11.3^{\prime} \mathrm{N}, 7^{\circ} 54.0^{\prime} \mathrm{E}\right)$ were collected in June 2007 using a 150 - and $500-\mu \mathrm{m}$ net aboard the research vessel "Aade". With a stereo microscope, the animals were sorted by genus with sterile tweezers and washed twice with sterile sea water. A culture of Acartia tonsa was grown from egg to adult stage at $18^{\circ} \mathrm{C}$ and $\mathrm{LD} 16: 8$ in filtered sea water with a salinity of 31 . These copepods were fed with
Rhodomonas sp. Adult specimens from laboratory-reared cultures of Acartia tonsa, field-caught Acartia sp. and Temora sp. were frozen in sterile tubes with one, five or ten individuals per tube.

\section{DNA extraction}

A number of cell lysis and DNA-extraction techniques were applied to the copepod samples (Fig. 1) covering a range of chemical and physical treatments. Additionally, protocols for differentiation of the attached bacterial community on copepod surfaces from the entire bacterial community were tested and are described later. Obviously, it would be of interest to differentiate between individual copepods, as no information is available on the variation of the bacterial community among specimens of copepods. On the other hand, given the very low densities of bacteria on copepods reported in previous studies, it was first of all necessary to determine the quantity of copepod specimens needed to obtain an adequate amount of bacterial DNA for further analysis. Due to the fact that the numbers of bacteria associated with copepods could be very low, the extraction techniques were first tested on batches of ten and five copepods per sample.

\section{Epibiotic bacterial community}

Copepod surface-attached bacteria were investigated using two protocols One used the Lyse-N-Go reagent (Pierce, Rockford, IL, USA) and the other employed lysozyme and SDS for cell lysis followed by phenol-chloroform DNA extraction and DNA precipitation with isopropanol, leaving the copepods intact.

Lyse-N-Go Entire copepods in batches of either ten, five or one individuals were treated with $10 \mu \mathrm{l}$ Lyse-N-Go reagent, followed by either one or two cycles of the thermocycle program recommended by the manufacturer. Lyse-N-Go isolates were directly subjected to PCR using either $2 \mu \mathrm{l}$ of pure extract or $2 \mu \mathrm{l}$ of a 1:10 dilution thereof, or were stored at $-20^{\circ} \mathrm{C}$ until further analysis.

Lysozyme/SDS Entire copepods in batches of either ten, five or one individuals were treated with $370 \mu \mathrm{l}$ of STEbuffer $(6.7 \%$ saccharose, $50 \mathrm{mM}$ Tris, $1 \mathrm{mM}$ EDTA, $\mathrm{pH}$ 8). Cell lysis was accomplished by incubating the samples with $100 \mu \mathrm{l}$ lysozyme $(10 \mathrm{mg} / \mathrm{ml})$ for $30 \mathrm{~min}$ at $37^{\circ} \mathrm{C}$ with gentle shaking at $400 \mathrm{rpm}$. Next, $50 \mu \mathrm{l}$ EDTA-Tris (250, $50 \mathrm{mM})$ and $30 \mu \mathrm{l}$ SDS-Tris-EDTA $(20 \%, 50,20 \mathrm{mM})$ were added and samples were incubated for $60 \mathrm{~min}$ at $50^{\circ} \mathrm{C}$ with gentle shaking. The salt concentration was increased by adding a $1 / 10$ volume of $\mathrm{NaCl}(5 \mathrm{M})$, and proteins were removed using 1 volume of phenol-chloroform (1:1). DNA 
Fig. 1 Schematic overview of sample preparation
Lab-grown Acartia tonsa

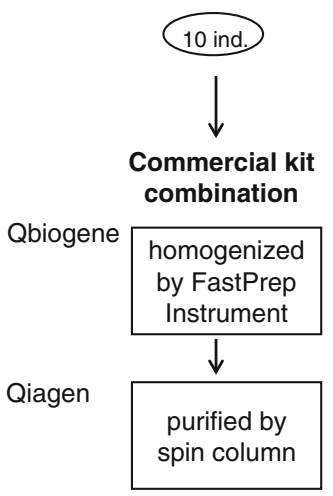

with or without proteinase $\mathrm{K}$
Lab-grown Acartia tonsa,

Acartia sp. and Temorasp.

from Helgoland Roads

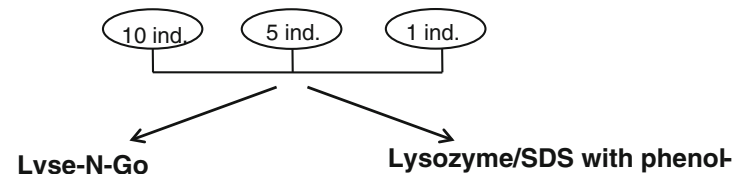

Lyse-N-Go
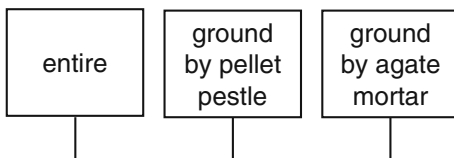
chloroform-extraction

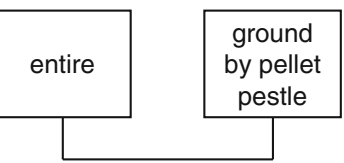

with one or two thermo cycles

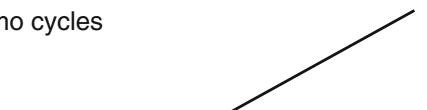

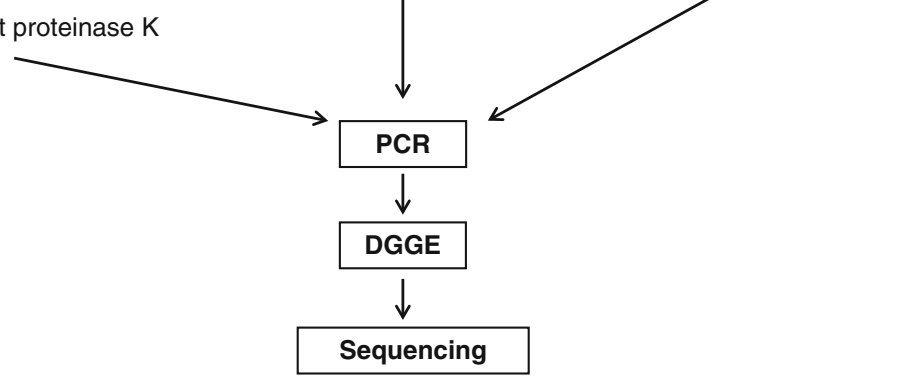

was then precipitated by overnight incubation with isopropanol at $-20^{\circ} \mathrm{C}$. Precipitates were washed with $75 \%$ ethanol and dried in a laminar flow cabinet for 15 min prior to resuspension with $10 \mu \mathrm{l}$ sterile water. DNA extracts were stored at $-20^{\circ} \mathrm{C}$ until further analysis.

\section{Entire bacterial community}

DNA of bacteria internally and externally associated with sampled copepods was extracted using one of three protocols after mechanical processing of each sample: first, treatment with Lyse-N-Go reagent; second, treatment with lysozyme/SDS followed by phenol-chloroform DNA extraction and precipitation with isopropanol; and third, a combination of two commercial DNA extraction kits.

Lyse-N-Go Copepods in batches of either ten, five or one individuals were suspended in $10 \mu \mathrm{l}$ of Lyse-N-Go reagent and transferred to a sterile agate mortar using sterile cut pipet tips. An additional $10 \mu \mathrm{l}$ of Lyse-N-Go reagent was added to the copepod suspension prior to grinding the sample with agate mortar and pestle by hand for $30 \mathrm{~s}$ in a laminar flow cabinet. The homogenised sample was pipetted into a sterile micro reaction tube. The agate mortar and pestle were then rinsed with an additional $10 \mu \mathrm{l}$ of Lyse-N-Go, which was added to the homogenate in the tube. Alternatively, another grinding procedure was conducted with a pellet pestle and pellet pestle motor (Kontes, Vineland, NJ, USA) for $30 \mathrm{~s}$ with
$10 \mu \mathrm{l}$ Lyse-N-Go reagent inside a sterile micro reaction tube before carrying out the recommended thermal cycle program one or two times.

Commercial kit combination BIO101 FastDNA Kit (Qbiogene, Carlsbad, CA, USA) and Blood and Tissue Kit (Qiagen, Hilden, Germany) were combined as follows: 1,000 $\mu \mathrm{l}$ of CLS-TC buffer (chaotropic lysis buffer, Qbiogene) was added to a sample of copepods (10 ind.) and pipetted with a sterile cut pipet tip into a matrix tube (Qbiogene). The sample was homogenised with FastPrep Instrument for $30 \mathrm{~s}$ at a speed setting of 4.0. After a 5min centrifugation step at $16000 \times g$, the entire supernatant was transferred into a new micro reaction tube. A $1 / 10$ volume of proteinase $\mathrm{K}$ (Roche, Mannheim, Germany) was added to one of the supernatant samples and another sample was left without proteinase to test whether a difference in the released amount of DNA or in the amount of PCR product exists. Both samples were then first incubated for $30 \mathrm{~min}$ at $37^{\circ} \mathrm{C}$ followed by $60 \mathrm{~min}$ incubation at $56^{\circ} \mathrm{C}$ in a thermomixer with gentle shaking. A $1 / 2$ volume of buffer AL (Qiagen) and a $1 / 2$ volume of ethanol (96\%) were added, and the solution was transferred to a spin column tube containing a silica matrix for DNA purification (Qiagen). DNA binding and elution steps were performed as recommended by the manufacturer, with one exception: The final elution step was conducted twice using $30 \mu \mathrm{l}$ of elution buffer AE (Qiagen) for each step. 
Lysozyme/SDS Copepods (10, 5, 1 ind.) were ground in $10 \mu \mathrm{l}$ STE-buffer for $30 \mathrm{~s}$ with pellet pestle, using pellet pestle motor followed by addition of $360 \mu \mathrm{l}$ of STE and $100 \mu$ lysozyme $(10 \mathrm{mg} / \mathrm{ml})$, respectively. The next steps were the same as described previously.

\section{PCR conditions}

PCR amplification of 16S rRNA gene fragments was performed using the bacteria specific primers P3-clamp (Muyzer et al. 1993) with a 40-bp GC-rich sequence at the $5^{\prime}$ end (5'-CGC CCG CCG CGC CCC GCG CCC GGC CCG CCG CCC CCG CCC CCC TAC GGG AGG CAG CAG-3') and 907r (5'-CCG TCA ATT CCT TTG AGT TT-3').

PCR mixtures with a volume of $50 \mu \mathrm{l}$ contained $5 \mu \mathrm{l}$ of $10 \times$ Taq buffer (Eppendorf, Hamburg, Germany), $8 \mu$ of Master Enhancer (Eppendorf) for initial PCRs and no enhancer for reamplification after DGGE, $300 \mu \mathrm{M}$ dNTPs (Promega, Mannheim, Germany), $0.2 \mu \mathrm{M}$ of each primer, 2 $\mathrm{U}$ of Taq DNA polymerase (Eppendorf) and either $2 \mu \mathrm{l}$ of pure or 1:10 diluted DNA prior to or $1 \mu \mathrm{l}$ after DGGE. 'Touchdown' PCR was performed as described by Sapp et al. (2007).

PCR fragments on $1.2 \%$ agarose gels were visualised by ethidium bromide $\left(0.5 \mathrm{mg} \mathrm{l}^{-1}\right)$ and images were captured with a ChemiDoc XRS System (BioRad, München, Germany). The thickness and intensity of each band visualised was used to gauge the relative volume of the corresponding product used for DGGE.

\section{DGGE}

All 16S rRNA gene amplicons were resolved on 6\% (w/v) polyacrylamide gels in $0.5 \times$ TAE buffer $(20 \mathrm{mM}$ TrisHCl, $10 \mathrm{mM}$ acetic acid, $0.5 \mathrm{mM}$ EDTA) with denaturing gradients of $15-55 \%$ urea/formamide $(100 \%$ denaturant contains $7 \mathrm{M}$ urea and $40 \%$ formamide). Electrophoresis was performed at $60^{\circ} \mathrm{C}$ and $150 \mathrm{~V}$ for $10 \mathrm{~h}$ (Sigler et al. 2004) using a DCode mutation detection system (BioRad). DGGE gels were stained with SYBRGold (Invitrogen, Karlsruhe, Germany). Imaging was performed with a ChemiDoc XRS System (BioRad). Prominent DGGE bands were excised, eluted (Sambrook et al. 1989), reamplified and confirmed by an additional DGGE.

As a standard for all DGGE gels, the combined PCRamplicons (P3-clamp/907r) of five bacteria (Polaribacter filamentus DSM 13964, Sulfitobacter mediterraneus DSM 12244, Arthrobacter agilis DSM 20550, Microbacterium maritypicum DSM 12512, Leifsonia aquatica DSM 20146) with different GC-contents were used.
Sequencing and phylogenetic analysis

Selected DGGE bands were excised, the DNA was eluted and reamplified using the primers $341 \mathrm{f}$ (without GC-clamp) (Muyzer et al. 1993) and 907r. PCR-products were checked on $1.2 \%(\mathrm{w} / \mathrm{v})$ agarose gels prior to sequencing. PCR products with the right size ( $\sim 566 \mathrm{bp})$ were excised from the agarose gels and used for sequencing.

DNA sequencing of PCR products was performed by Qiagen GmbH using an ABI PRISM 3700 DNA Analyzer (Applied Biosystems, Foster City, CA, USA). Sequencing primers were $341 \mathrm{f}$ and $907 \mathrm{r}$. Nearest relatives were searched using BLAST (http://www.ncbi.nlm.nih.gov; Altschul et al. 1997).

Sequence data were checked for the presence of PCRamplified chimeric sequences by the CHECK_CHIMERA program (Cole et al. 2003). The ARB software package (http://www.arb-home.de) was used for phylogenetic analysis (Ludwig et al. 2004). After addition of sequences to the ARB 16S rDNA sequences database (release May 2005), alignment was carried out with the Fast Aligner integrated in the program and refined by comparison of closest relatives retrieved by BLAST. Sequences with more than 1,300 nucleotides were used to calculate phylogenetic trees. The ARB "parsimony interactive" tool was used to add partial sequences to respective trees. Phylogenetic relationships were deduced by the neighbour joining method including the correction algorithm of Felsenstein (1993).

Nucleotide sequence accession numbers

The sequences obtained in this study are available from GenBank under accession numbers FJ226496-FJ226515.

\section{Results}

DNA extraction and PCR

DNA extracts yielded from the different extraction techniques were not quantified before the use as PCR template, because it was very plausible that especially with the ground copepods also copepod DNA was extracted. Nevertheless, PCR amplification of the targeted 16S rRNA gene region was successful. The differences observed between the extraction methods tested here are described in the following paragraphs.

\section{Epibiotic bacterial community}

Lyse- $\mathrm{N}-\mathrm{Go}$ Applying the Lyse-N-Go treatment using one thermocycle on ten isolated copepods yielded sufficient 
bacterial DNA for successful bacterial 16S rRNA gene amplification by PCR, regardless of the copepod group (laboratory-grown Acartia tonsa, field-caught Acartia sp. or field-caught Temora sp.) selected. Employing an additional thermocycle during DNA extraction yielded a higher quantity of PCR product. Replicate extractions using Lyse$\mathrm{N}$-Go reagent with one or two thermocycles on one or five copepods per sample yielded DNA which, when used as a PCR template, led to only inconsistent results regarding the amplification of PCR product.

Lysozyme/SDS Enzymatic/detergent cell lysis followed by phenol-chloroform DNA extraction performed on ten, five or one copepod(s) in suspension yielded PCR amplifiable bacterial DNA in all cases. Quality checks of the amplification products revealed consistently higher band intensity than products derived from Lyse-N-Go DNA extracts. No variation among the three investigated copepod groups and replicates were observed.

\section{Entire bacterial community}

Lyse-N-Go Grinding ten, five or one copepod individual(s) in Lyse-N-Go reagent with an agate mortar resulted in inconsistent success with PCR amplification. PCR products generated using DNA extracts from pellet-pestlehomogenised copepod suspensions as template yielded PCR products with a higher concentration than those generated from agate mortar DNA extracts. Amplification was inconsistent when the pellet pestle technique was applied to five or one copepod(s). The procedure with two thermocycles yielded higher amounts of detectable PCR product than that with one thermocycle, irrespective of which extraction steps were taken before.

Commercial kit combination Combining the BIO101 FastDNA Kit to extract DNA from copepod tissue and the silica-based DNA purification in spin-columns from the Blood and Tissue Kit successfully retrieved PCR-amplifiable DNA. The amounts of DNA and PCR product detected were comparable to Lyse-N-Go treatment with pellet pestle. Incubation with proteinase $\mathrm{K}$ yielded lower quantities of PCR product.

Lysozyme/SDS The highest amount of PCR product for all investigated copepod groups was achieved using the lysozyme/SDS treatment in combination with phenolchloroform DNA extraction together with pellet pestle homogenisation. PCR amplification was consistent for copepod suspensions with ten, five or one individual(s). PCR product quality checks revealed that amplification with DNA from phenol-chloroform DNA extracts of laboratory-grown and field-caught Acartia sp. resulted in notably less amount of PCR product compared to those of field-caught Temora sp. (Fig. 2).

\section{DGGE}

Bacteria-specific PCR products obtained from DNA extracted with different methods generated notably different DGGE banding patterns. A lower number of DGGE bands were observed with PCR products received from the
Fig. 2 Comparison of PCRproduct amounts of the three investigated copepod groups. a Using intact copepods for phenol-chloroform DNA extraction and $\mathbf{b}$ using pelletpestle-ground copepods
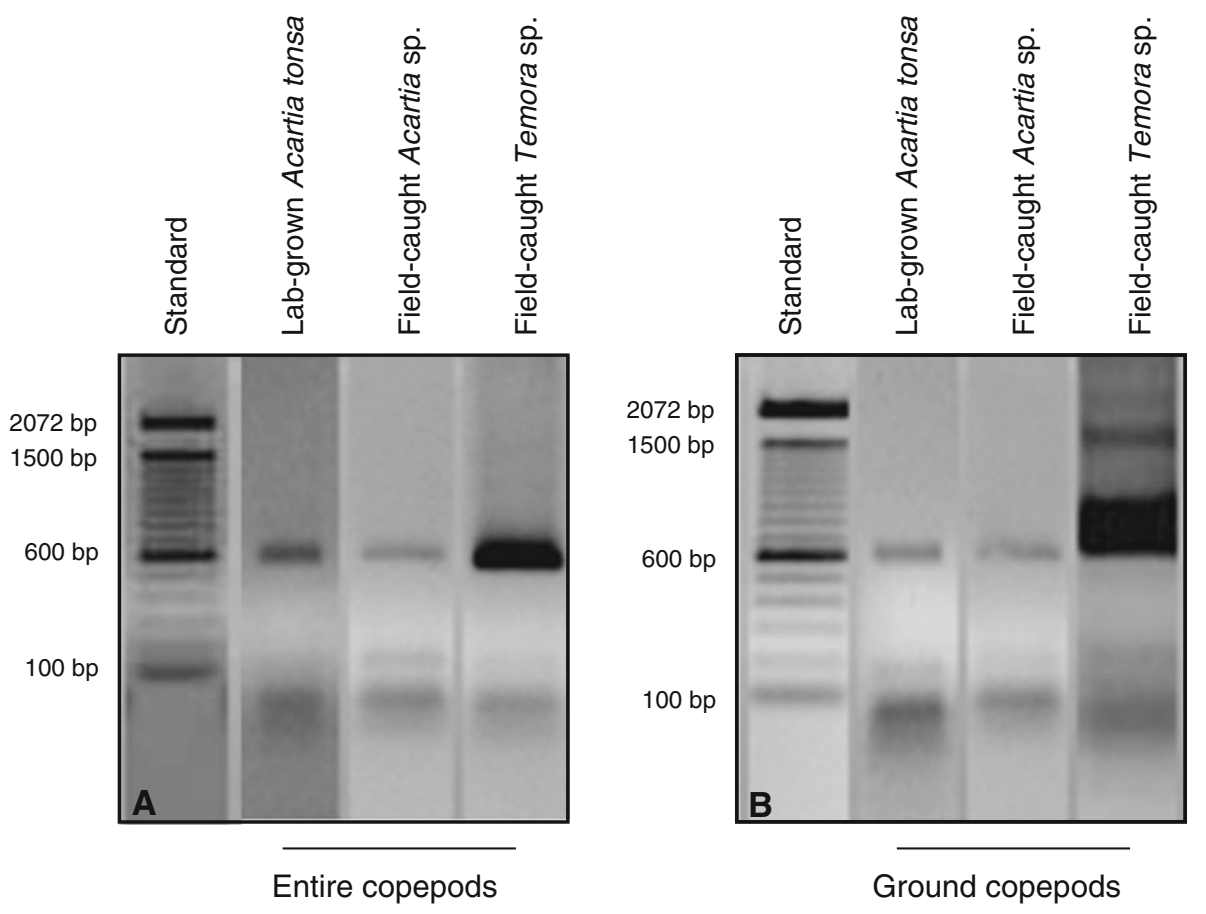
Fig. 3 DGGE banding patterns of the three investigated copepod groups. DNA was extracted using pellet pestle and phenol-chloroform DNA extraction. Arrows with numbers show cut and sequenced DGGE bands. Numbers on standard-bands mark the gel positions of the PCR-amplicons of five bacteria: 1 Polaribacter filamentus DSM 13964, 2 Sulfitobacter mediterraneus DSM 12244, 3 Arthrobacter agilis DSM 20550, 4 Microbacterium maritypicum DSM 12512, 5 Leifsonia aquatica DSM 20146

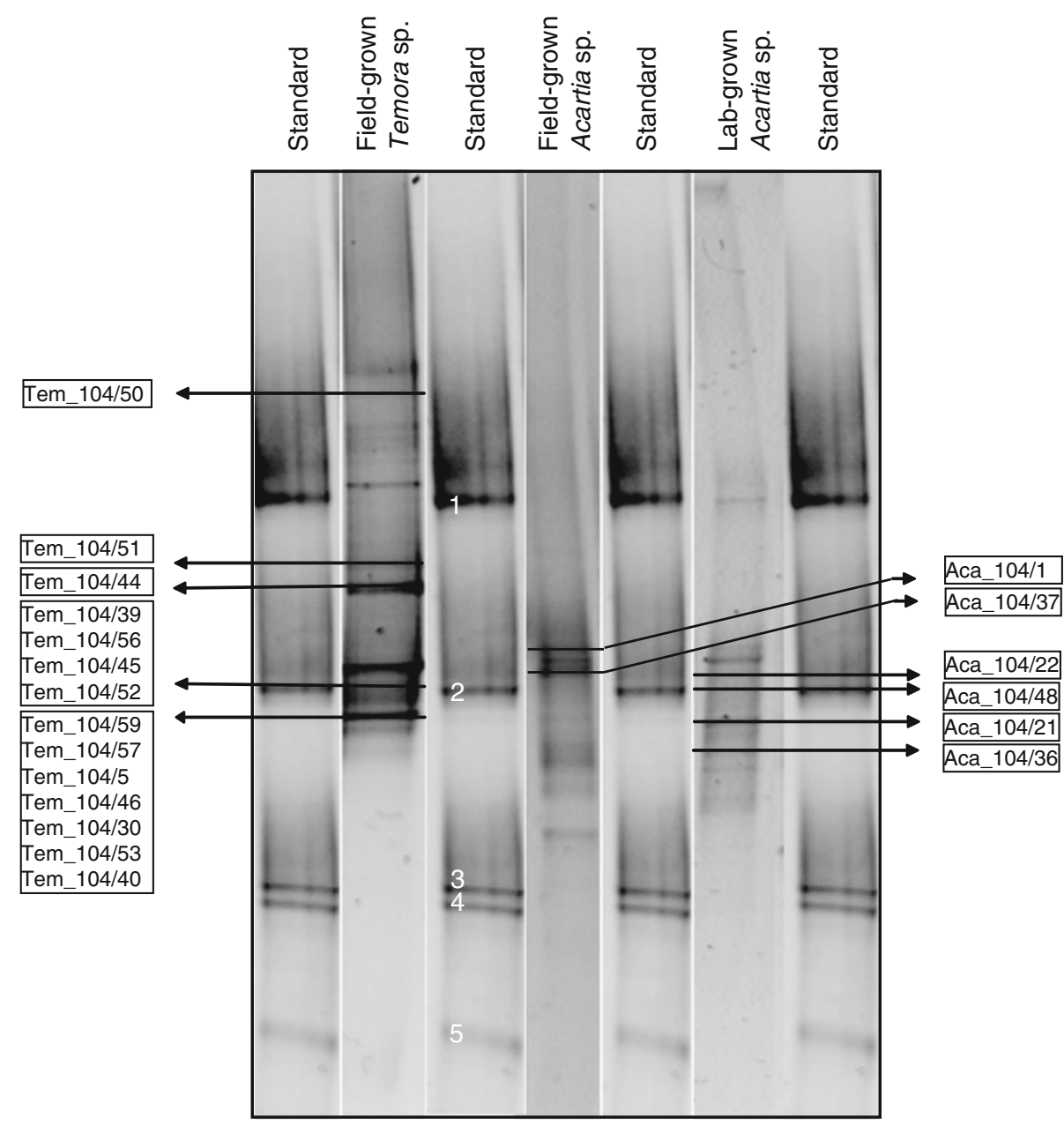

Lyse-N-Go procedure compared to banding patterns obtained with PCR products achieved from phenol-chloroform DNA extraction.

Up to 20 distinct DGGE bands were generated using PCR products from Temora $s p$. and approximately 10 for both groups of Acartia sp. irrespective of the number of copepods used for extraction. Clear differences are notable between the laboratory-grown and field-caught Acartia $s p$. groups (Fig. 3). The highest number of DGGE bands and a very stable and reproducible pattern could be observed using PCR products of phenol-chloroform extracted DNA regardless of whether the copepods were left intact or ground by pellet pestle prior to analysis. DGGE finger print patterns showed higher numbers of bands when using the ground copepods than the intact ones (Fig. 4). Unexpectedly, some bands are only visible in the intact copepods (Fig. 4, lower white box).

Sequencing and phylogenetic analysis

Prominent DGGE bands were sequenced from excised agarose gel bands. Sequence data of 20 excised bands from ground copepods could be retrieved representing nine different bacterial phylotypes (Table 1). Closest relatives of the sequenced bands derived from BLAST analyses are also listed in Table 1. The results revealed many close matches with $98-100 \%$ similarity to bacterial $16 \mathrm{~S}$ rRNA gene sequences in the GenBank. Seventeen sequences of DGGE bands showed high similarity with sequences of Alphaproteobacteria, only one with Deltaproteobacteria, and two with Bacteroidetes. No Gammaproteobacteria were observed.

Comparison of sequence data of excised bands appearing at the same position in DGGE gels revealed identical closest relatives in most cases (e.g. Tem_104/59, Tem_104/57, Tem_104/5, Tem_104/46, Tem_104/30, Tem_104/53 and Tem_104/40). Moreover, bands Aca_104/21, Aca_104/22 and Aca_104/48 resulted in the same sequence although they were excised at different gel positions (Table 1).

A neighbour-joining tree (Fig. 5) of selected members of the Alphaproteobacteria, Deltaproteobacteria and Bacteroidetes shows that the excised bands sequences Tem_104/59 (Tem_104/57, Tem_104/5, Tem_104/46, 
Fig. 4 Differences in the DGGE-banding pattern of intact or ground copepods. White boxes highlight the differences

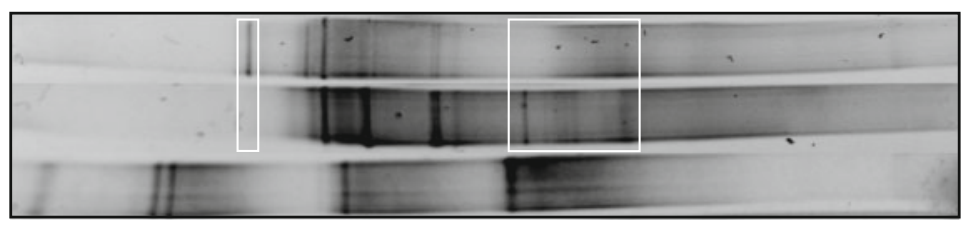

Standard

Table 1 Closest relatives to the sequenced DGGE bands

\begin{tabular}{|c|c|c|c|c|c|c|}
\hline Band & Host & $\begin{array}{l}\text { Similarity } \\
(\%)\end{array}$ & $\begin{array}{l}\text { Alignment } \\
\text { length }\end{array}$ & $\begin{array}{l}\text { Accession } \\
\text { number }\end{array}$ & Closest relative & $\begin{array}{l}\text { Taxonomic affiliation } \\
\text { as reported in GenBank }\end{array}$ \\
\hline Tem_104/59 & Temora sp. field & 99 & $510 / 511$ & EU005307 & Clone G3-45 & Uncultured Alphaproteobacterium \\
\hline Tem_104/57 & & 99 & $510 / 511$ & & & \\
\hline Tem_104/5 & & 99 & $473 / 474$ & & & \\
\hline Tem_104/46 & & 99 & $460 / 461$ & & & \\
\hline Tem_104/30 & & 99 & $476 / 477$ & & & \\
\hline Tem_104/53 & & 100 & $435 / 435$ & & & \\
\hline Tem_104/40 & & 100 & $463 / 463$ & & & \\
\hline Tem_104/52 & Temora sp. field & 100 & $465 / 465$ & DQ839261 ${ }^{\mathrm{a}}$ & DGGE band NS16 & Uncultured Alphaproteobacterium \\
\hline Tem_104/39 & & 99 & $459 / 462$ & & & \\
\hline Tem_104/45 & & 99 & $460 / 464$ & & & \\
\hline Tem_104/56 & & 98 & $484 / 490$ & & & \\
\hline Tem_104/44 & Temora sp. field & 97 & $439 / 451$ & DQ839261 ${ }^{\mathrm{a}}$ & DGGE band NS16 & Uncultured Alphaproteobacterium \\
\hline Tem_104/50 & Temora sp. field & 97 & $510 / 522$ & EF215784 & Clone PV2-37 & Uncultured Bacteroidetes \\
\hline Tem_104/51 & Temora sp. field & 91 & $496 / 540$ & DQ831068 & Isolate LP-OTU63 & Uncultured Bacteroidetes \\
\hline Aca_104/21 & Acartia sp. lab & 98 & $452 / 459$ & DQ372849 & Clone NH10_29 & Uncultured Alphaproteobacterium \\
\hline Aca_104/22 & Acartia sp. lab & 97 & $442 / 453$ & DQ372849 & Clone NH10_29 & Uncultured Alphaproteobacterium \\
\hline Aca_104/48 & Acartia sp. lab & 96 & $412 / 426$ & DQ372849 & Clone NH10_29 & Uncultured Alphaproteobacterium \\
\hline Aca_104/36 & Acartia sp. lab & 95 & $402 / 420$ & DQ395758 & Clone ctg_CGOF389 & Uncultured Alphaproteobacterium \\
\hline Aca_104/1 & Acartia sp. field & 96 & $440 / 454$ & DQ234217 & Clone DS134 & Uncultured Alphaproteobacterium \\
\hline Aca_104/37 & Acartia sp. field & 93 & $443 / 472$ & DQ911789 & DGGE band GB03-a10-p & Uncultured Deltaproteobacterium \\
\hline
\end{tabular}

${ }^{a}$ Sequence accession number of copepod-associated bacteria found by Møller et al. (2007)

Tem_104/30, Tem_104/53 and Tem_104/40 are not shown in the tree) cluster with a sequence of a surface-attached marine bacterium of the Roseobacter clade (EU005307) (Dang et al. 2008). Aca_104/21, Aca_104/22 and Aca_104/ 48 are strongly related to an uncultured marine bacterium (DQ372849) (Morris et al. 2006), while the sequences Tem_104/44, Tem_104/52 and Tem_104/45 (Tem_104/39 and Tem_104/56 are not shown in the tree) are grouped with the sequences of copepod-associated bacteria (DQ839253 and DQ839261) found by Møller et al. (2007). Phylotype Aca_104/1 clusters with a bacterium detected in a Taiwanese mangrove ecosystem (DQ234217) (Liao et al. 2007), while sequence Tem_104/37 is related to a surface water bacterium from the German Bight (DQ911789). Sequence Tem_104/50 is grouped with an uncultured surface-attached bacterium (EF215784) (Dang et al. 2008), whereas Aca_104/36 is related to a deep sea octacoral bacterium (DQ395758).

\section{Discussion}

Marine bacteria have a strong affinity to surfaces (Zobell 1943; Costerton et al. 1978; Cooksey and WigglesworthCooksey 1995; Carman and Dobbs 1997). In many cases, such as with marine snow, this can be explained by the greater availability of resources in these aggregates, or in case of surface layers and biofilms, by some sort of protective features of these structures (Matz et al. 2005). In the case of the bacterial communities associated in- and outside of the marine copepods, little is known about their function and even less about their identity. Obviously, bacteria located around the mouth and anus could well be consuming waste and excretory products of the animals, but to our knowledge, no information as to their functional role exists. In fact, it is not even known precisely whether these bacteria are simply epibionts, or possibly harmful or pathogenic for the copepods themselves, for other aquatic 


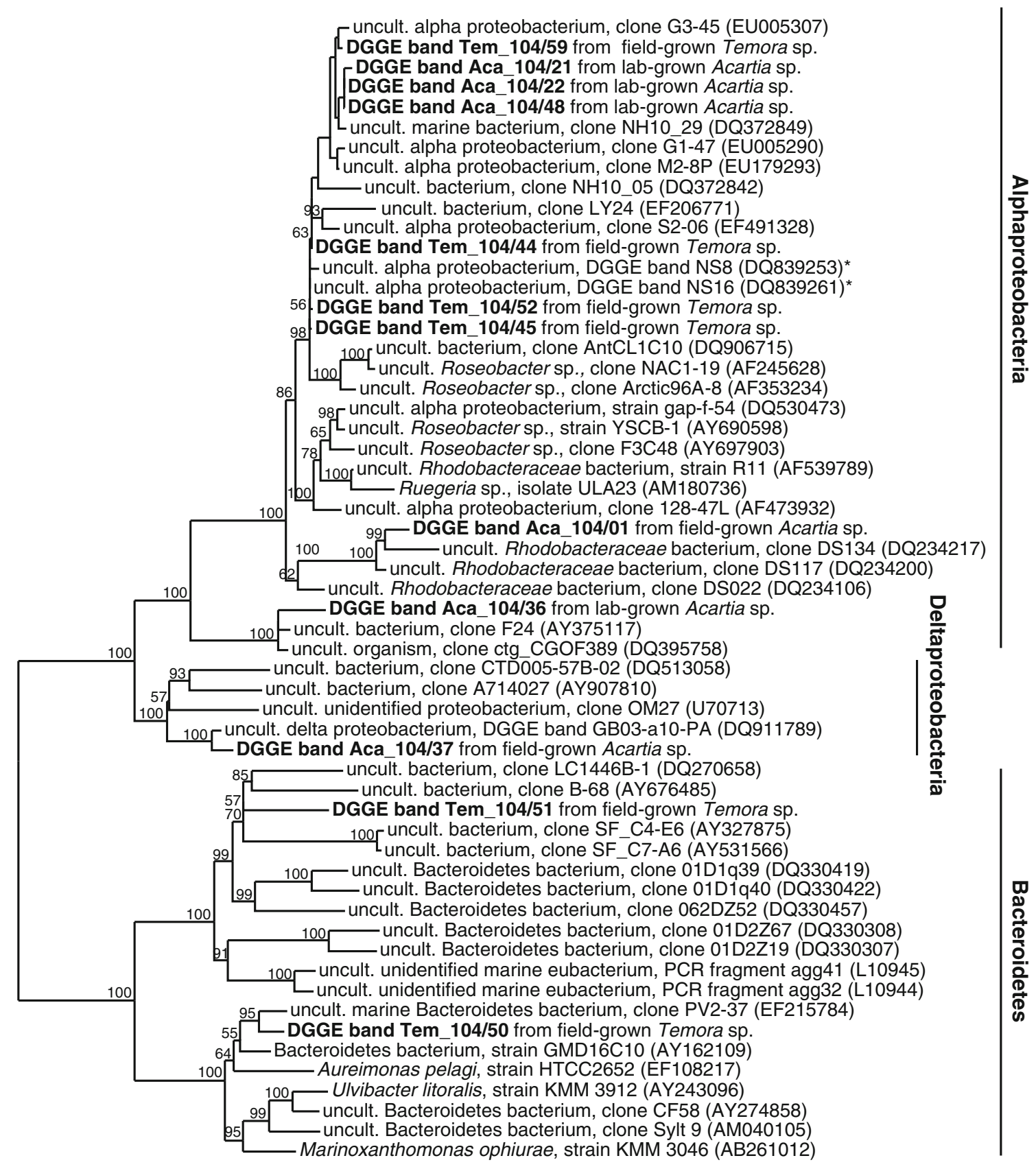

0.10

Fig. 5 Phylogenetic tree of Alphaproteobacteria, Deltaproteobacteria and members of the Bacteroidetes. GenBank accession numbers are given in parentheses. Bootstrap values above 50\% are displayed.

animals or even for humans. In earlier studies, on the identification of the copepod-associated bacteria Sochard et al. (1979) used culture techniques to characterise and quantify the bacteria with the well-known disadvantages of cultivation (Muyzer et al. 1993). So the use of culture-independent techniques, or a combination of culture-dependent and -independent techniques (Peter and Sommaruga 2008) could possibly shed more light on the
Marked with stars: Accession numbers of copepod-associated bacteria found by Møller et al. (2007)

identity of the copepod-associated bacteria. For example, Tang and co-workers (Tang 2005; Tang et al. 2006a, b) investigated the bacteria on copepod carcasses and faecal pellet colonisation using molecular techniques. Their DGGE results showed that the bacterial community of copepod carcasses alter over the time of incubation. But from the results of this study, however, it remains unclear whether the bacteria were already associated with the 
living copepods or whether they colonised the animals after their death. In the case of the faecal pellets, it is unclear whether they were colonised by the bacteria in the gut or after defecation. Additionally, the bacteria found in these studies were not identified.

To our knowledge, Møller et al. (2007) were the first to investigate the bacterial community of the marine copepod Calanus sp. with PCR-DGGE followed by sequencing of DGGE bands. They reported difficulties with bacterial DNA-extraction from these copepods. These authors initially used a modified enzyme/SDS-extraction technique without the use of phenol-chloroform, but it seemed that the complete lysis of the copepods with this method resulted in inhibition of the following PCR reaction. The extraction method was changed accordingly and they continued with a commercial DNA extraction kit where the copepods were not visibly lysed.

Therefore, one of the aims of our study was to develop an extraction protocol suited for the analysis of copepodassociated bacterial DNA. This optimised DNA extraction technique is absolutely essential for molecular biology, since a modification of the extraction method is required for each different sample and each tissue (Roose-Amsaleg et al. 2001). Two previous studies on the extraction of DNA from copepod-associated bacteria for PCR-DGGE analysis have been published so far (Tang et al. 2006b; Møller et al. 2007). Tang and co-workers used a treatment with zirconium beads and hot phenol-chloroform-isoamylalcohol, whereas Møller et al. used two other different methods. This shows that so far no standard DNA-extraction technique has been established.

In the present study, a modified lysozyme/SDS phenolchloroform DNA extraction protocol was compared with a combination of two commercially available DNA-isolation kits and a commercial cell lysis reagent. These techniques differ in sample processing time and also in their efficiency. In addition, three different grinding procedures were tested to have the possibility to compare the surfaceattached as well as the entire internal and external bacterial communities of the copepods. Due to the fact that, especially when using grinding techniques, also copepod DNA was extracted, the extracted DNA amounts were not quantified in this study. When the DNA extracts were used as PCR template, however, bacterial PCR product could be obtained in most cases.

Generally, the Lyse-Go-procedure was the fastest of the investigated techniques. It took only a few minutes to prepare the samples without grinding the copepods. With this procedure, there was no visible lysis of the copepods. Grinding with the pellet pestle took another $30 \mathrm{~s}$, while grinding with the agate mortar required more time for transferring the copepods into the mortar and back to the test tube. Additionally, during this transfer, a lot of material was lost due to the large surface area of pestle and mortar, resulting in very faint PCR bands. For PCR reaction of the Lyse-N-Go processed samples, the mixture had to be diluted 10 fold, to get an adequate PCR product. This might be due to the presence of some inhibitory substances, as already described by Møller et al. (2007), when using two or more microlitres of the original mixture.

The combination of two commercial DNA extraction kits was even more time consuming. A combination of two kits was required because of the grinding procedure of the copepods. The lysing-matrix tube and the CLS-TC buffer (Bio101) were used with the corresponding FastPrep Instrument (Bio1O1) to homogenise the copepods, while the spin column of the Qiagen Blood and Tissue Kit was used to purify the DNA.

The lysozyme/SDS phenol-chloroform DNA extraction was the most time consuming procedure, because the precipitation step took place over night. However, the PCR product amount yield was best of all investigated procedures, regardless of whether the copepods were intact or ground. In contrast, Møller et al. (2007) reported that their modified enzyme/SDS extraction protocol led to a release of PCR-inhibiting substances which was not observed in our procedure, as we used a phenol-chloroform step after enzyme/SDS-extraction to get rid of these substances. Therefore, from our investigations, we conclude that the lysozyme/SDS phenol-chloroform DNA extraction method is the one best suited, allowing even for the analysis of single copepod individuals.

The band intensities of PCR-products on ethidium bromide-stained agarose gels of phenol-chloroform extracts retrieved from laboratory-grown and field-caught Acartia sp. and field-caught Temora sp. were compared. Based on strong PCR product signals on an agarose gel, it can be assumed that field-caught Temora sp. may harbour more bacteria than field-caught and laboratory-grown Acartia sp. (Fig. 2). Since the copepods were not measured or weighed in this study, nor were the attached bacteria counted, we only presume that Temora sp. harbour more bacteria than Acartia sp. because of their larger size. However, this will need further investigations.

The DGGE finger printing analysis revealed clear differences among the investigated DNA extraction techniques. The banding patterns varied both in band numbers and band intensities. This might be due to low DNA concentrations, resulting in too low template concentrations for production of an adequate amount of PCR product. If the quantities of PCR product are too low, no DGGE-band can be formed. Therefore, it has to be considered that DGGE bands of a single copepod species can vary in number, although they harbour the identical bacterial community. These results underline the importance of a highly efficient DNA-extraction technique, which is 
essential for investigating the bacterial communities not only of copepods.

Distinct banding patterns are evident for each of the three copepod groups subjected to phenol-chloroform DNA extraction treatment and PCR-DGGE (Fig. 3). Hence, it is probable that specific copepod genera harbour different bacterial communities. Additionally, there were differences in the DGGE-banding patterns of intact and ground copepods extracted with phenol-chloroform, clearly suggesting that there are differences between the bacteria populations in- and outside of the copepods. To gain more information about this topic, it would be necessary to investigate, e.g., the gut of the copepods separately, because this should be the body part inside the copepods which harbours the most bacteria. That work would also contribute to answer the question of whether the gut microflora of these important links of the marine food web is transient or permanent (Carman and Dobbs 1997).

For sequencing, the PCR products of the appropriate size were excised from the agarose gel to exclude unspecific byproducts (approx. $100 \mathrm{bp)} \mathrm{(Fig.} \mathrm{2).} \mathrm{After} \mathrm{sequencing} \mathrm{the}$ most prominent DGGE bands of the investigated copepod groups two bacterial phyla were found by sequence analysis. The identified phylotypes in this study belonged to the Alphaproteobacteria, Deltaproteobacteria and the Bacteroidetes. The phylotypes were related to marine surfacewater bacteria as well as to surface-attached bacteria. One DGGE band (Tem_104/51) was related with a bacterium associated with larval stages of the tropical rock lobster (Panulirus ornatus) (Payne et al. 2007).

Four identified sequences of Temora. sp.-associated bacteria (Tem_104/52, Tem_104/39, Tem_104/45 and Tem_104/56) (Table 1) were strongly related to two sequences of attached bacteria of the copepod Calanus sp. found by Møller et al. (2007). These bacteria were members of the Roseobacter lineage of the Alphaproteobacteria.

The finding that copepod-attached bacterial phylotypes were related to the Roseobacter lineage is not surprising, considering that members of the Roseobacter lineage are among the most predominant bacterial phylotypes recovered from marine plankton clone libraries and have been found to be dominant in the North Sea (Eilers et al. 2001).

Some excised bands (Aca_104/21, Aca_104/22 and Aca_104/48) result in the same sequence although they were excised from different gel positions (Table 1). This is probably due to microheterogeneity of different rRNAoperons present in this bacterial species, as was reported previously (Nübel et al. 1996; v. Wintzingerode et al. 1997).

Although several other studies observed members of the genus Vibrio among the attached bacteria on copepods (Sochard et al. 1979; Huq et al. 1983; Tamplin et al. 1990), no members of this genus were found in our study.
Members of the bacterial genus Vibrio seem to have a particularly strong affinity for all marine surfaces, especially under nutrient-limiting conditions (Dawson et al. 1981; Tamplin et al. 1990; Carman and Dobbs 1997). Nalin and co-workers (Nalin et al. 1979) found a connection between chitinous surfaces and Vibrios. Huq and coworkers (Huq et al. 1983. 1984), using culture techniques, detected both $V$. cholerae and $V$. parahaemolyticus preferentially attached to planktonic copepods relative to other bacteria (e.g. Escherichia coli and Pseudomonas sp.). The absence of Vibrio sp. in the present study cannot be explained yet. However, maybe the DGGE-bands which represented Vibrio sp. were not excised because they were too faint or the sequencing of the excised band failed. Muyzer et al. (1993) and Murray et al. (1996) reported that PCR-DGGE is sensitive enough to detect bacteria which make up only $1-2 \%$ of bacterial populations in the mixed assemblage of selected bacterial strains. Thus, the PCRDGGE method tends to bias towards the predominant groups within a community (v. Wintzingerode et al. 1997; Casamayor et al. 2000). Moreover, the detection limit of the PCR-DGGE method is affected by the relative abundance of a population as well as by ribosomal RNA (rrn) operon copy numbers (Kan et al. 2006). Nonetheless, substantial information about the species composition can be obtained from complex microbial communities by DGGE analysis (Muyzer and Smalla 1998).

The present and other similar studies allow only a small insight into the identity of the bacteria colonising the exoskeleton and the intestine of marine copepods. Hence, for further insights into the bacterial communities of different copepod genera, or even species, as well as into the copepod gut microflora and faecal pellet-associated bacteria, more studies have to be conducted. The outcomes of these studies strongly depend on highly efficient molecular biological techniques. A suitable bacterial DNA extraction technique for this research was developed and could be evaluated in this study.

Acknowledgments This study is part of the Helgoland Foodweb project. We would like to thank Katja Kreisel for her helping hands, Martin Löder, Christina Gebühr, Florian Hantzsche and Katherina Schoo for stimulating discussions and the latter one for introduction into the world of copepods and the donation of copepod eggs.

\section{References}

Altschul SF, Madden TL, Schaffer AA, Zhang J, Zhang Z, Miller W, Lipman DJ (1997) Gapped BLAST and PSI-BLAST: a new generation of protein database search programs. Nucl Acids Res 25:3389-3402

Azam F, Fenchel T, Field JG, Gray JS, Meyer-Reil LA, Thingstad F (1983) The ecological role of water-column microbes in the sea. Mar Ecol Prog Ser 10:257-263 
Carman KR, Dobbs FC (1997) Epibiotic microorganisms on copepods and other marine crustaceans. Microsc Res Tech 37:116-135

Casamayor EO, Schäfer H, Bañeras L, Pedrós-Alió C, Muyzer G (2000) Identification of and spatio-temporal differences between microbial assemblages from two neighboring sulfurous lakes: comparison by microscopy and denaturing gradient gel electrophoresis. Appl Environ Microbiol 66:499-508

Cole JR, Chai B, Marsh TL, Farris RJ, Wang Q, Kulam SA, Chandra S, McGarrell DM, Schmidt TM, Garrity GM, Tiedje JM (2003) The ribosomal database project (RDP-II): previewing a new autoaligner that allows regular updates and the new prokaryotic taxonomy. Nucl Acids Res 31:442-443

Cooksey KE, Wigglesworth-Cooksey B (1995) Adhesion of bacteria and diatoms to surfaces in the sea: a review. Aquat Microb Ecol 9:87-96

Costerton JW, Geesey GG, Cheng K-J (1978) How bacteria stick. Sci Am 238:86-95

Cushing DH (1989) A difference in structure between ecosystems in strongly stratified waters and in those that are only weakly stratified. J Plankton Res 11:1-13

Dang H, Li T, Chen M, Huang G (2008) Cross-ocean distribution of Rhodobacterales bacteria as primary surface colonizers in temperate coastal marine waters. Appl Environ Microbiol 74:52-60

Dawson MP, Humphrey BA, Marshall KC (1981) Adhesion: a tactic in the survival strategy of a marine Vibrio during starvation. Curr Microbiol 6:195-199

Eilers H, Pernthaler J, Peplies J, Glöckner FO, Gerdts G, Amann R (2001) Isolation of novel pelagic bacteria from the German Bight and their seasonal contributions to surface picoplankton. Appl Environ Microbiol 67:5134-5142

Felsenstein J (1993) Phylip (phylogeny inference package), version 3.5c. Department of Genetics, University of Washington, Seattle

Hansen B, Bech G (1996) Bacteria associated with a marine planktonic copepod in culture. I. Bacterial genera in seawater, body surface, intestines and fecal pellets and succession during fecal pellet degradation. J Plankton Res 18:257-273

Hasegawa T, Koike I, Mukai H (2001) Fate of food nitrogen in marine copepods. Mar Ecol Prog Ser 210:167-174

Huq A, Small EB, West PA, Huq MI, Rahman R, Colwell RR (1983) Ecological relationships between Vibrio cholerae and planktonic crustacean copepods. Appl Environ Microbiol 45:275-283

Huq A, West PA, Small EB, Huq MI, Colwell RR (1984) Influence of water temperature, salinity, and $\mathrm{pH}$ on survival and growth of toxigenic Vibrio cholerae serovar 01 associated with live copepods in laboratory microcosms. Appl Environ Microbiol 48:420-424

Kan J, Wang K, Chen F (2006) Temporal variation and detection limit of an estuarine bacterioplankton community analyzed by denaturing gradient gel electrophoresis (DGGE). Aquat Microb Ecol 42:7-18

Liao P-C, Huang B-H, Huang S (2007) Microbial community composition of the Danshui river estuary of Northern Taiwan and the practicality of the phylogenetic method in microbial barcoding. Microb Ecol 54:497-507

Ludwig W, Strunk O, Westram R, Richter L, Meier H, Yadhukumar, Buchner A, Lai T, Steppi S, Jobb G, Förster W, Brettske I, Gerber S, Ginhart AW, Gross O, Grumann S, Hermann S, Jost R, König A, Liss T, Lüssmann R, May M, Nonhoff B, Reichel B, Strehlow R, Stamatakis A, Stuckmann N, Vilbig A, Lenke M, Ludwig T, Bode A, Schleifer K-H (2004) Arb: a software environment for sequence data. Nucl Acids Res 32:1363-1371

Matz C, McDougald D, Moreno A, Yung P, Yildiz F, Kjelleberg S (2005) Biofilm formation and phenotypic variation enhance predation-driven persistence of Vibrio cholerae. PNAS 102:16819-16824
Møller EF (2005) Sloppy feeding in marine copepods: prey-sizedependent production of dissolved organic carbon. J Plankton Res 27:27-35

Møller EF, Nielsen TG (2001) Production of bacterial substrate by marine copepods: effect of phytoplankton biomass and cell size. J Plankton Res 23:527-536

Møller EF, Thor P, Nielsen TG (2003) Production of DOC by Calanus finmarchicus, C. glacialis and C. hyperboreus through sloppy feeding and leakage from fecal pellets. Mar Ecol Prog Ser 262:185-191

Møller EF, Riemann L, Søndergaard M (2007) Bacteria associated with copepods: abundance, activity and community composition. Aquat Microb Ecol 47:99-106

Morris RM, Longnecker K, Giovannoni SJ (2006) Pirellula and OM43 are among the dominant lineages identified in an Oregon coast diatom bloom. Environ Microbiol 8:1361-1370

Murray AE, Hollibaugh JT, Orrego C (1996) Phylogenetic compositions of bacterioplankton from two California estuaries compared by denaturing gradient gel electrophoresis of $16 \mathrm{~S}$ rDNA fragments. Appl Environ Microbiol 62:2676-2680

Muyzer G, Smalla K (1998) Application of denaturing gradient gel electrophoresis (DGGE) and temperature gradient electrophoresis (TGGE) in microbial ecology. Antonie van Leeuwenhoek 73:127-141

Muyzer G, de Waal EC, Uitterlinden AG (1993) Profiling of complex microbial populations by denaturing gradient gel electrophoresis analysis of polymerase chain reaction-amplified genes coding for 16S rRNA. Appl Environ Microbiol 59:695-700

Nagasawa S (1989) Bacterial epibionts of copepods. Science Prog 73:169-176

Nagasawa S, Simidu U, Nemoto T (1985) Scanning electron microscopy investigation of bacterial colonization of the marine copepod Acartia clausi. Mar Biol 87:61-66

Nalin DR, Daya V, Reid A, Levine MM, Cisneros L (1979) Adsorption and growth of Vibrio cholerae on chitin. Infect Immun 25:768-770

Nübel U, Engelen B, Felske A, Snaidr J, Wieshuber A, Amann RI, Ludwig W, Backhaus H (1996) Sequence heterogeneities of genes encoding 16S rRNAs in Paenibacillus polymyxa detected by temperature gradient gel electrophoresis. J Bacteriol 178:5636-5643

Olsen SN, Westh P, Hansen BW (2005) Real-time quantification of microbial degradation of copepod fecal pellets monitored by isothermal microcalorimetry. Aquat Microb Ecol 40:259-267

Payne MS, Hall MR, Sly L, Bourne DG (2007) Microbial diversity within early-stage cultured Panulirus ornatus phyllosomas. Appl Environ Microbiol 73:1940-1951

Peter H, Sommaruga R (2008) An evaluation of methods to study the gut bacterial community composition of freshwater zooplankton. J Plankton Res 30:997-1006

Roose-Amsaleg CL, Garnier-Sillam E, Harry M (2001) Extraction and purification of microbial DNA from soil and sediment samples. Appl Soil Ecol 18:47-60

Sambrook J, Fritsch EF, Maniatis T (1989) Molecular cloning: A laboratory manual, Cold Spring Harbor Laboratory Press

Sapp M, Wichels A, Wiltshire KH, Gerdts G (2007) Bacterial community dynamics during the winter-spring transition in the North Sea. FEMS Microbiol Ecol 59:622-637

Sieburth JM, Willis P-J, Johnson KM, Burney CM, Lavoie DM, Hinga KR, Caron DA, French FW III, Johnson PW, Davis PG (1976) Dissolved organic matter and heterotrophic microneuston in the surface microlayers of the North Atlantic. Science 194:1415-1418

Sigler WV, Miniaci C, Zeyer J (2004) Electrophoresis time impacts the denaturing gradient gel electrophoresis-based assessment of bacterial community structure. J Microbiol Methods 57:17-22 
Sochard MR, Wilson DF, Austin B, Colwell RR (1979) Bacteria associated with the surface and gut of marine copepods. Appl Environ Microbiol 37:750-759

Steinberg DK, Nelson NB, Carlson CA, Prusak AC (2004) Production of chromophoric dissolved organic matter (CDOM) in the open ocean by zooplankton and the colonial cyanobacterium Trichodesmium spp. Mar Ecol Prog Ser 267:45-56

Tamplin ML, Gauzens AL, Huq A, Sack DA, Colwell RR (1990) Attachment of Vibrio cholerae serogroup 01 to zooplankton and phytoplankton of Bangladesh waters. Appl Environ Microbiol 56:1977-1980

Tang KW (2005) Copepods as microbial hotspots in the ocean: effects of host feeding activities on attached bacteria. Aquat Microb Ecol 38:31-40
Tang KW, Freund CS, Schweitzer CL (2006a) Occurrence of copepod carcasses in the lower Chesapeake Bay and their decomposition by ambient microbes. Estuar Coast Shelf Sci 68:499-508

Tang KW, Hutalle KML, Grossart H-P (2006b) Microbial abundance, composition and enzymatic activity during decomposition of copepod carcasses. Aquat Microb Ecol 45:219-227

v. Wintzingerode F, Göbel UB, Stackebrandt E (1997) Determination of microbial diversity in environmental samples: pitfalls of PCRbased rRNA analysis. FEMS Microbiol Rev 21:213-229

Zobell CE (1943) The effect of solid surfaces upon bacterial activity. J Bacteriol 46:39-56 